\title{
Water-the Nation's Fundamental Climate Issue A White Paper on the U.S. Geological Survey Role and Capabilities
}

Circular 1347 


\section{Water-the Nation's Fundamental Climate Issue A White Paper on the U.S. Geological Survey Role and Capabilities}

By Harry F. Lins, Robert M. Hirsch, and Julie Kiang

Circular 1347 


\section{U.S. Department of the Interior \\ KEN SALAZAR, Secretary \\ U.S. Geological Survey \\ Marcia K. McNutt, Director}

\section{U.S. Geological Survey, Reston, Virginia: 2010}

For more information on the USGS - the Federal source for science about the Earth, its natural and living resources, natural hazards, and the environment, visit http://www.usgs.gov or call 1-888-ASK-USGS.

For an overview of USGS information products, including maps, imagery, and publications, visit http://www.usgs.gov/pubprod.

To order this and other USGS information products, visit http://store.usgs.gov.

Any use of trade, product, or firm names is for descriptive purposes only and does not imply endorsement by the U.S. Government.

Although this report is in the public domain, permission must be secured from the individual copyright owners to reproduce any copyrighted materials contained within this report.

Suggested citation:

Lins, Harry F., Hirsch, Robert M., and Kiang, Julie, 2010, Water-the Nation's Fundamental Climate Issue: A White Paper on the U.S. Geological Survey Role and Capabilities: U.S. Geological Survey Circular 1347, 9 p., available at http://pubs.usgs.gov/circ/1347. 


\section{Contents}

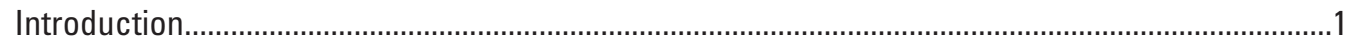

Understanding Climate and Water..............................................................................................2

Climate-Sensitive Hydrologic Data ...........................................................................................

Climate-Directed Hydrologic Analyses ....................................................................................2

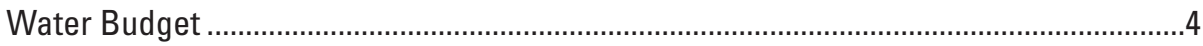

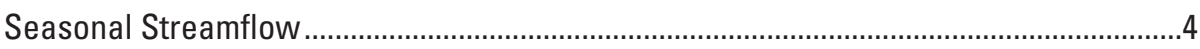

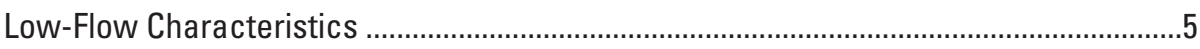

Flood and High-Flow Characteristics ......................................................................

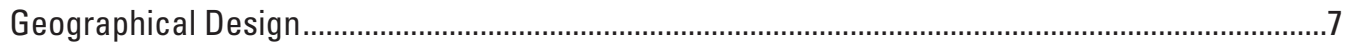

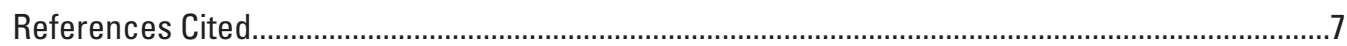

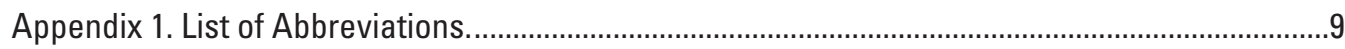

\section{Figures}

1. Relation of annual runoff to precipitation and temperature ..............................................

2. Number of streamgaging stations with statistically significant $(p \leq 0.05)$ increasing and decreasing trends in annual minimum daily streamflow ......................5

3. Annual peak discharges, at the USGS streamgage, Red River of the North, Grand Forks, North Dakota, 1882 through 2009 .............................................6

\section{Conversion Factors}

\begin{tabular}{lcl}
\hline \multicolumn{1}{c}{ Multiply } & \multicolumn{1}{c}{ By } & \multicolumn{1}{c}{ To obtain } \\
\hline & \multicolumn{1}{c}{ Length } & \\
\hline inch (in.) & 2.54 & centimeter $(\mathrm{cm})$ \\
inch (in.) & 25.4 & millimeter $(\mathrm{mm})$ \\
foot (ft) & 0.3048 & meter $(\mathrm{m})$ \\
\hline \multicolumn{1}{c}{ Flow rate } & \\
\hline cubic foot per second $\left(\mathrm{ft}^{3} / \mathrm{s}\right)$ & 0.02832 & cubic meter per second $\left(\mathrm{m}^{3} / \mathrm{s}\right)$ \\
cubic foot per second per square & 0.01093 & cubic meter per second per square \\
$\quad$ mile $\left[\left(\mathrm{ft}^{3} / \mathrm{s}\right) / \mathrm{mi}^{2}\right]$ & & kilometer $\left[\left(\mathrm{m}^{3} / \mathrm{s}\right) / \mathrm{km}^{2}\right]$ \\
cubic foot per day $\left(\mathrm{ft}^{3} / \mathrm{d}\right)$ & 0.02832 & cubic meter per day $\left(\mathrm{m}^{3} / \mathrm{d}\right)$ \\
inch per hour $(\mathrm{in} / \mathrm{h})$ & 0.0254 & meter per hour $(\mathrm{m} / \mathrm{h})$ \\
inch per year $(\mathrm{in} / \mathrm{yr})$ & 25.4 & millimeter per year $(\mathrm{mm} / \mathrm{yr})$ \\
mile per hour $(\mathrm{mi} / \mathrm{h})$ & 1.609 & kilometer per hour $(\mathrm{km} / \mathrm{h})$ \\
\hline
\end{tabular}

Temperature in degrees Celsius $\left({ }^{\circ} \mathrm{C}\right)$ may be converted to degrees Fahrenheit $\left({ }^{\circ} \mathrm{F}\right)$ as follows:

${ }^{\circ} \mathrm{F}=\left(1.8 x^{\circ} \mathrm{C}\right)+32$

Temperature in degrees Fahrenheit $\left({ }^{\circ} \mathrm{F}\right)$ may be converted to degrees Celsius $\left({ }^{\circ} \mathrm{C}\right)$ as follows:

${ }^{\circ} \mathrm{C}=\left({ }^{\circ} \mathrm{F}-32\right) / 1.8$ 


\title{
Water-the Nation's Fundamental Climate Issue A White Paper on the U.S. Geological Survey Role and Capabilities
}

\author{
By Harry F. Lins, Robert M. Hirsch, and Julie Kiang
}

\section{Introduction}

Of all the potential threats posed by climatic variability and change, those associated with water resources are arguably the most consequential for both society and the environment (Waggoner, 1990). Climatic effects on agriculture, aquatic ecosystems, energy, and industry are strongly influenced by climatic effects on water. Thus, understanding changes in the distribution, quantity and quality of, and demand for water in response to climate variability and change is essential to planning for and adapting to future climatic conditions. A central role of the U.S. Geological Survey (USGS) with respect to climate is to document environmental changes currently underway and to develop improved capabilities to predict future changes. Indeed, a centerpiece of the USGS role is a new Climate Effects Network of monitoring sites. Measuring the climatic effects on water is an essential component of such a network (along with corresponding effects on terrestrial ecosystems).

The USGS needs to be unambiguous in communicating with its customers and stakeholders, and with officials at the Department of the Interior, that although modeling future impacts of climate change is important, there is no more critical role for the USGS in climate change science than that of measuring and describing the changes that are currently underway. One of the best statements of that mission comes from a short paper by Ralph Keeling (2008) that describes the inspiration and the challenges faced by David Keeling in operating the all-important Mauna Loa Observatory over a period of more than four decades. Ralph Keeling stated: "The only way to figure out what is happening to our planet is to measure it, and this means tracking changes decade after decade and poring over the records."

There are three key ideas that are important to the USGS in the above-mentioned sentence. First, to understand what is happening requires measurement. While models are a tool for learning and testing our understanding, they are not a substitute for observations. The second key idea is that measurement needs to be done over a period of many decades. When viewing hydrologic records over time scales of a few years to a few decades, trends commonly appear. However, when viewed in the context of many decades to centuries, these short-term trends are recognized as being part of much longer term oscillations. Thus, while we might want to initiate monitoring of important aspects of our natural resources, the data that will prove to be most useful in the next few years are those records that already have long-term continuity. USGS streamflow and groundwater level data are excellent examples of such longterm records. These measured data span many decades, follow standard protocols for collection and quality assurance, and are stored in a database that provides access to the full period of record.

The third point from the Keeling quote relates to the notion of "poring over the records." Important trends will not generally jump off the computer screen at us. Thoughtful analyses are required to get past a number of important but confounding influences in the record, such as the role of seasonal variation, changes in water management, or influences of quasi-periodic phenomena, such as El Niño-Southern Oscillation (ENSO) or the Pacific Decadal Oscillation (PDO). No organization is better situated to pore over the records than the USGS because USGS scientists know the data, qualityassure the data, understand the factors that influence the data, and have the ancillary information on the watersheds within which the data are collected.

To fulfill the USGS role in understanding climatic variability and change, we need to continually improve and strengthen two of our key capabilities: (1) preserving continuity of long-term water data collection and (2) analyzing and interpreting water data to determine how the Nation's water resources are changing.

Understanding change in water resources to date and predicting change into the future must be done in full recognition of the other factors that influence water availability, including changes in water use, land use, the design and operation of water infrastructure, and the depletion of groundwater. There is widespread debate about the relative importance of nonclimatic factors versus climatic factors in determining water conditions and characteristics over the coming decades (Lins and Stakhiv, 1998). Differentiating climatic from nonclimatic effects is, therefore, a critical component of any effective 
assessment of how climate has, is, and will affect the Nation's water resources. Moreover, such assessments are critically dependent upon a quality-assured, spatially and temporally comprehensive water-resources database.

For more than 100 years, the USGS has been monitoring the Nation's rivers and groundwater resources, and currently maintains the world's most sophisticated information system of surface-water, groundwater, water-quality, and water-use data. The USGS is uniquely positioned to play a central role in providing both data and analyses to address the recently recognized increment of hydrologic uncertainty associated with climatic variability and change (Moss and Lins, 1989).

The USGS draws upon two decades of climate change research related to hydroclimatology - the study of hydrologic events and conditions within their climatologic context. USGS research provides an empirical basis for integrating the physical sources of variability in a hydrologic time series with the statistical properties of the varying driving force itself. This research also highlights several themes where our incomplete understanding of important hydrologic processes and conditions continues to serve as an impediment to the broader incorporation of climate change information in water-resources planning and design. Thus, expanding our understanding of these processes is key to developing improved capabilities for dealing with climate uncertainty in the field of water-resources planning and management.

\section{Understanding Climate and Water}

Climate affects all aspects of hydrology and water resources through the water budget. Among the more critical elements of this issue to the Nation are how climate is affecting low flows and drought, high flows and flooding, and the seasonality (timing) of streamflow. Each of these factors can only be meaningfully understood where there exists a spatially and temporally adequate record of high-quality hydrologic observations, such as those derived from the USGS streamgaging network.

\section{Climate-Sensitive Hydrologic Data}

Information on the flow of rivers is a national asset that safeguards lives and property and ensures adequate water resources for a healthy economy (Hirsch and Norris, 2001). As noted by the National Research Council (1999), "Streamflow data collected by the USGS ... form the cornerstone for national, regional, and local efforts ... by providing continued, up-to-date information about water conditions and understanding of hydrologic phenomena. " In this context, an important component of the USGS National Streamflow Information Program (NSIP) is to provide data that are minimally affected by human activities for the study of regional streamflow characteristics and assessments of trends due to factors such as changes in climate, land use, and water use. Within NSIP, the stations providing such data are referred to as sentinel watersheds, and most are derived from the existing USGS Hydro-Climatic Data Network (HCDN). Sentinel watersheds also include the 36 discharge-monitoring stations of the USGS Hydrologic Benchmark Network (HBN).

HCDN stations were identified to provide a unique database of high-quality, climate-sensitive observations, specifically for evaluating climatic effects on streamflow (Slack and Landwehr, 1992). For nearly two decades, the observations from these stations have been the principal data used by researchers worldwide in studies of United States hydroclimatic patterns, variations, and trends. The criteria used to identify these stations have been adopted by hydrological services in other countries and, more recently, by the World Meteorological Organization's Commission for Hydrology as part of its efforts to establish a global climate-sensitive streamflow database [World Meteorological Organization (WMO), 2004]. When established in 1992, the HCDN consisted of 1,659 stations. Over time, many of these stations have been discontinued and there are numerous gaps in the geographical distribution of stations, particularly in the western United States and at higher elevations. An effort is currently underway to update the listing of HCDN stations using a predictive model of climate-sensitive watershed conditions based on hydrological alteration criteria (Carlisle and others, 2009).

The Hydrologic Benchmark Network (HBN) was established in 1963 to provide long-term measurements of streamflow and water quality in areas that are minimally affected by human activities. These data are used to study long-term trends in surface-water flow and water chemistry and as a benchmark against which to identify changes in flow and chemistry in developed watersheds (Murdoch and others, 2005). HBN, HCDN, and the corresponding NSIP sentinel watersheds are, therefore, logical and essential elements of the incipient USGS Climate Effects Network.

\section{Climate-Directed Hydrologic Analyses}

The effect of climate (particularly precipitation and temperature) on hydrology (particularly streamflow) has been a focus of research among USGS hydrologists for six decades. The classic hydroclimatic study by Langbein and others (Geological Survey Circular 52, 1949) graphically related mean annual runoff in the United States to mean annual precipitation and temperature, and was a standard reference used in water balance work through the 1980s (fig. 1). Some of this reference's more enduring aspects were its illustration of (1) how runoff, for a given annual precipitation, decreases as temperature increases; (2) how runoff, for a given temperature, increases with precipitation; and (3) how the numerical difference between precipitation and runoff, for a given temperature, increases with precipitation and ultimately reaches a constant representing the limiting rate of evapotranspiration. This work served as the basis for many early climate change, water-resources impact studies during the 1980s and early 


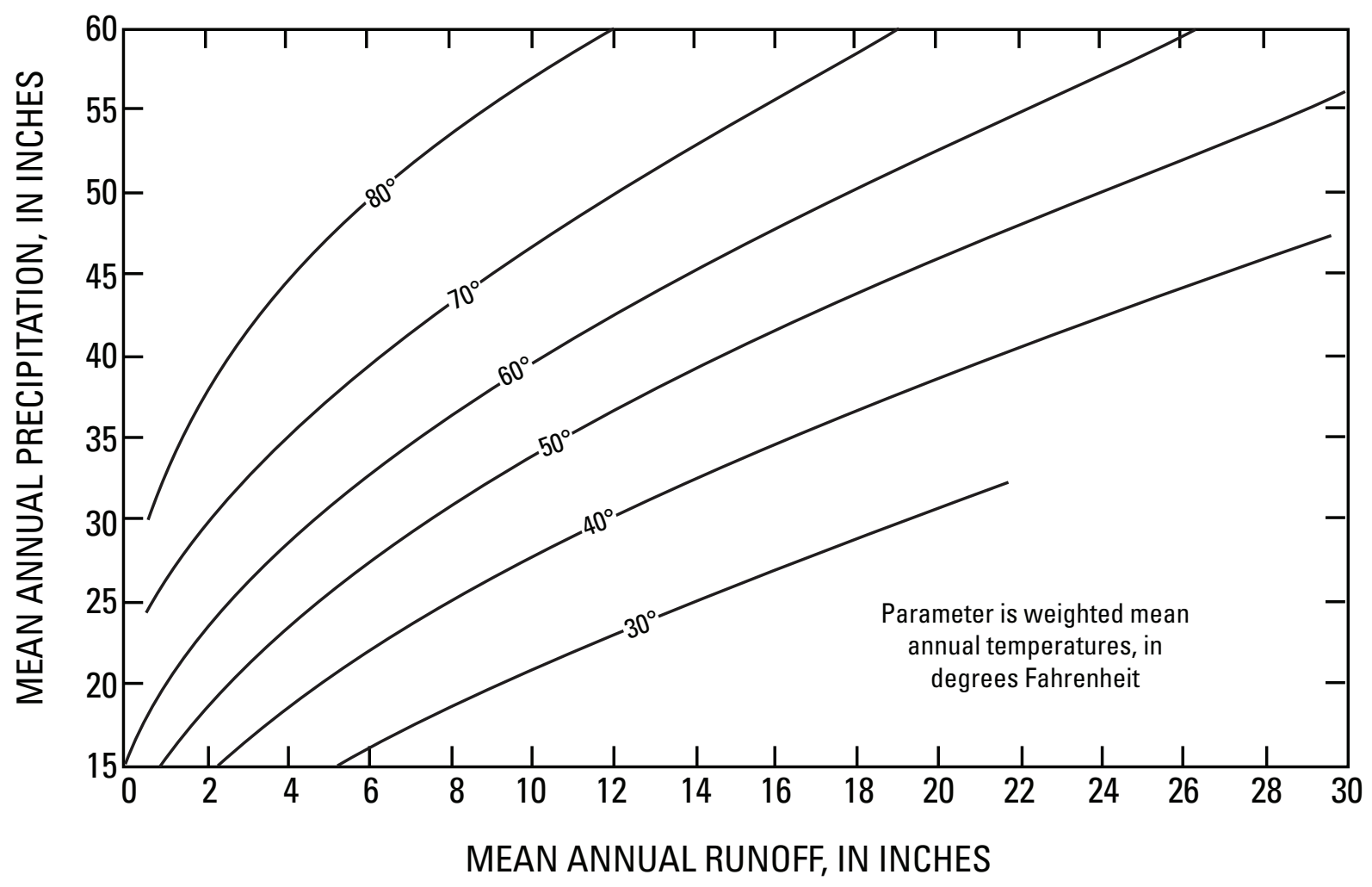

Figure 1. Relation of annual runoff to precipitation and temperature. [Source: Langbein and others, 1949.]

1990s, when the emphasis shifted to studying such interactions using numerical models.

During the past 15 years, studies of climate change impacts on water have increasingly made use of general circulation model (GCM) simulations of future climate states [Intergovernmental Panel on Climate Change (IPCC), 1995, 2001, 2007]. Most such studies use model-simulated temperature and precipitation to draw inferences about water-related impacts. As most projected climate change effects related to water resources (for example, changes in flooding, drought, and the seasonality of snowmelt-generated streamflow) are subgrid (local) scale processes, they are not resolved explicitly within the models. Rather, they are inferred from the changes in temperature and precipitation simulated for the grid cell surrounding the location of interest.

The temperature increases simulated by the models occur in response to rising concentrations of atmospheric carbon dioxide $\left(\mathrm{CO}_{2}\right)$ that, in turn, cause increases in both evaporation and precipitation. This increase in atmospheric heat and moisture is frequently referred to as indicating an "enhanced hydrological cycle." Since being reported initially in the Second Assessment Report (Intergovernmental Panel on Climate Change (IPCC), 1995), the enhanced hydrological cycle has been cited generally as the explanation for why floods and droughts are expected to increase with increasing $\mathrm{CO}_{2}$ concentrations. Changes in the timing of snowmelt-generated streamflow are mentioned as resulting from increasing winter and spring temperatures, whereby mountain snows melt and resultant peak streamflows occur earlier in the year. Increasing spring and summer season temperatures lengthen the warm season and the amount of evaporation, and are expected to reduce further the water supply in lakes, reservoirs, and rivers by summer's end.

Are these water-related impacts of $\mathrm{CO}_{2}$-induced climate change already manifesting themselves within the United States? Answering this question is much more complicated than it may appear. Not all changes occurring in the climate system are the result of increased $\mathrm{CO}_{2}$ concentrations. Indeed, the extent to which observed climatic variations over the past three decades are the result of $\mathrm{CO}_{2}$ emissions versus changes in natural factors (for example, El Niño-Southern Oscillation (ENSO), Pacific Decadal Oscillation (PDO), Atlantic Multidecadal Oscillation (AMO), solar variations, etc.) is unknown. However, existing streamflow data provide the requisite empirical basis for understanding both short-term (seasonal to decadal) hydrologic variations and long-term (multidecadal to centennial) hydrologic trends, and for testing hypotheses regarding the hydrologic response to climate change. These same data also make it possible to differentiate hydrologic changes due to climate from those resulting from other important forcing factors, such as urbanization, groundwater development, dam building, changes in the area of irrigated agriculture, changes in the area of row-crop agriculture, and changes in water withdrawals or consumption.

The following four topical segments represent issues of critical concern to the Nation's water-resources planning and 
management communities, and have been highlighted as possibly being adversely impacted by simulated changes in climate. The USGS has conducted a number of studies on these issues during the past two decades (many of which are cited), but never in the context of a systematic or comprehensive program of investigations. As a result, substantive and crucial gaps remain in each issue area, particularly with respect to understanding operative climate forcing. Collectively, the contents of these topical segments constitute a unique program of hypothesis testing on key assumptions associated with climate change impacts on water resources. Critical questions and issues that the USGS proposes to address are highlighted in bold print.

\section{Water Budget}

Over time, changes in mean discharge can pose substantial problems, but can also pose opportunities for waterresources managers. Although the effect of climatic change on hydrologic extremes has tended to receive the most attention, Lins and Cohn (2003) analyzed the sensitivity of streamflow to changes in precipitation and found that the precipitation sensitivity of mean streamflow is much greater than that of flood flows. They also found that the greater the return period of the flood, the lower the precipitation sensitivity. This finding suggests that changes in climate are more likely to produce changes in the mean state of hydrological regimes than in hydrological extremes. From a water-resources planning and management perspective, therefore, the more crucial questions to answer may be associated with how to take advantage of opportunities posed by potential increases in mean discharge, as well as how to prepare appropriately for the threats posed by potential decreases in mean discharge.

The following questions identify the types of information that USGS researchers need to provide to be of maximum value to water managers: Have multidecadal changes in mean discharge occurred and, if so, are these variations distinct from observed centennial changes? Have changes occurred in the relation of annual or seasonal discharge to annual or seasonal precipitation? To date, few studies have attempted to document such changes, and those that have, generally have done so at scales not appropriate for resource planning and design purposes. There are 352 hydrologic accounting units in the United States, and not only are these units the basis for managing NSIP, they are the basis for planning and managing the Nation's water-resources infrastructure as well. Thus, answers to the above two questions need to be sought at the hydrologic-accounting unit level.

\section{Seasonal Streamflow}

Water-resources systems are designed and managed in consideration of the prevailing seasonal characteristics of precipitation, both the amount and type, and their effect on seasonal streamflow. In most water-resources regions of the
United States, streamflow decreases to its minimum value in September, coincident with the end of the water year. ${ }^{1}$ Exceptions are the Souris-Red-Rainy and Upper Colorado waterresource regions where snow and river ice in mid-winter cause the annual minimum to occur in February (Lins and Slack, 2005). Maximum streamflow is more temporally variable, occurring over the 5-month period from February (California water-resource region) to June (Missouri water-resource region), and generally reflects the timing of snowmelt and (or) the month of maximum rainfall.

Concern has been raised that in a scenario where the climate is warmer than today's climate, reservoir contents in regions where streamflows are primarily snowmelt driven, rather than rainfall driven, could be reduced earlier in the summer than at present, leading to reduced water availability during the season of peak water demand. This reduction in availability would result from a combination of increased evaporation and transpiration from warmer temperatures and a lengthening of the warm season, as well as increased irrigation demand. Moreover, several recent studies have shown that in mountainous areas of the Western United States and in northern New England, the midpoint in the total volume of streamflow for the first 6 months of the calendar year appears to be occurring 1 to 3 weeks earlier than in the past (Dettinger and Cayan, 1995; McCabe and Clark, 2005; Stewart and others, 2005; Hodgkins and Dudley, 2006); however, no reduction in summer season flows has been observed (Lins and Slack, 2005).

Tracking and understanding the reasons for such shifts are important because of the impact they can have on waterresources and aquatic ecosystems management. For example, reservoir rule curves, which were developed using streamflow observations from decades ago, may need to be modified to ensure the maintenance of adequate municipal and agricultural water supplies, in-stream flow for aquatic ecosystems, or to provide flood protection. Despite the insights gained from recent USGS research, numerous questions remain. Are the shifts that are currently taking place important to water management (water supply, flood mitigation, and aquatic ecosystem integrity)? If not, why not, and how long would a shift have to continue before it becomes important to these kinds of issues? Although climate change has been implicated as the likely cause for the observed hydrologic changes, to what extent could multidecadal climatic-oceanic oscillations or changes in groundwater development or water use be responsible for these observed changes? Being able to differentiate and quantify the water-resources response to both climatic and nonclimatic drivers of hydrologic change is critical for any effective program of adaptive water management.

\footnotetext{
${ }^{1}$ The 12-month period from October through September. The water year is designated by the calendar year in which it ends and which includes 9 of the 12 months. For example, the year ending September 30, 1992, is called the "1992 water year."
} 


\section{Low-Flow Characteristics}

The characteristics of low flows in rivers and streams are important metrics for water managers who must meet a growing number of water-supply requirements, particularly when low flows persist over an extended period as during drought. Low flows are also critical for managing water quality where pollutant concentrations must be maintained below regulatory thresholds required by the Clean Water Act. Low flows, which regularly occur during late summer in most of the United States, can be affected by changes in precipitation, evapotranspiration, and, in snow-melt dominated areas, by shifts in seasonality (that is, late winter and spring temperatures). Annual low flows are distinct from drought flows primarily in terms of their temporal duration and magnitude. The IPCC $(1995,2001,2007)$ model simulations indicate drying in midcontinental areas during the summer and the possibility of more severe droughts. However, empirical studies of trends in low flows have not shown evidence of a general decrease in low flows (Svensson and others, 2005). Indeed, several studies have found substantial increases in low flows in the United States over the past half century (Lins and Slack, 1999; 2005; McCabe and Wolock, 2002; fig. 2).

Explaining variations and changes in low streamflow is complicated by the fact that low flows are sensitive to nonclimatic factors, particularly to manmade water storage, water use, and groundwater depletion. The following research questions are critical to gaining additional insight into how and to what extent climate is affecting low flows: Is there a pattern of change in 1-day, 7-day, 14-day, or 28-day low flows? Are we seeing an unexpected number of new record low flows (more than expected or less than expected by chance)? If low flows are changing, what are the relative influences

\section{Number of Increasing Trends}

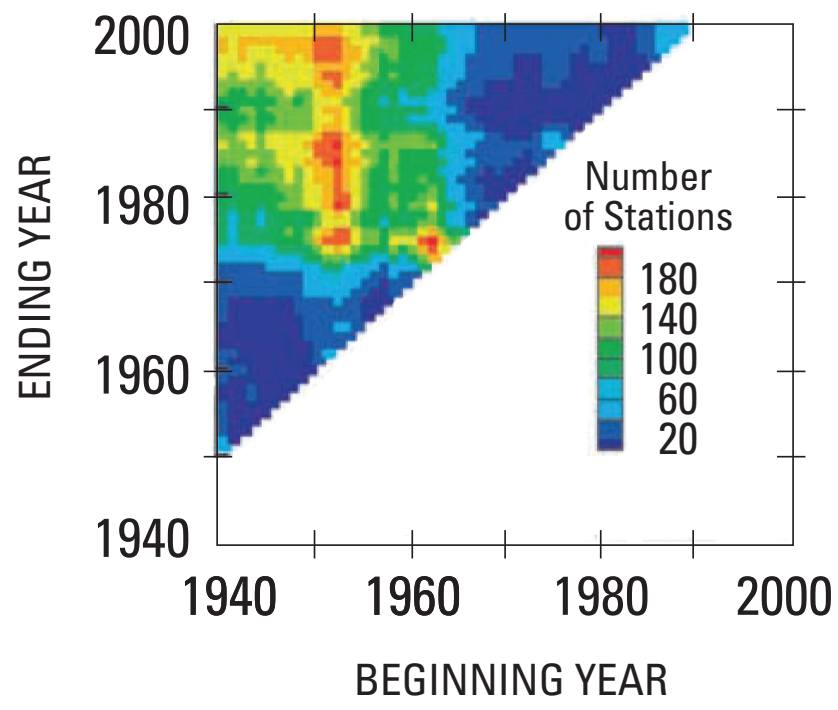

of changing water use, groundwater depletion, reservoir storage, or intrabasin transfers on low flows? To what extent is it possible to predict regional low flows seasonally and annually based on North Atlantic and North Pacific sea-surface temperatures as hypothesized by McCabe and others (2004)?

\section{Flood and High-Flow Characteristics}

Floods are the most costly natural hazard in the United States, causing an average of 140 fatalities and $\$ 5$ billion in damages each year (O'Connor and Costa, 2003). Any change in the factors that affect flood hazards can, therefore, dramatically impact the Nation's social and economic well-being. Increased urban and suburban development on flood plains has, for example, substantially increased the mortality and economic losses from floods (Pielke and Downton, 2000). Moreover, as noted earlier, climate model simulations have been interpreted as indicating that more and larger floods will occur in response to a warming-induced, enhanced hydrological cycle. To date, numerous studies of annual maximum (daily mean) streamflow have found no evidence of an increasing trend in high streamflow (Lins and Slack, 1999; 2005; McCabe and Wolock, 2002; Douglas and others, 2000; and Kundzewicz and others, 2005). One study, using different data (annual maximum based on monthly mean streamflow) and methods, reported an increase in the frequency of floods having an exceedance probability $<0.01$ during the 20th century (Milly and others, 2002). A concern associated with all of these studies, however, is that annual maximum streamflow records include many observations that are not true (out-of-bank) floods. A more representative dataset for

\section{Number of Decreasing Trends}

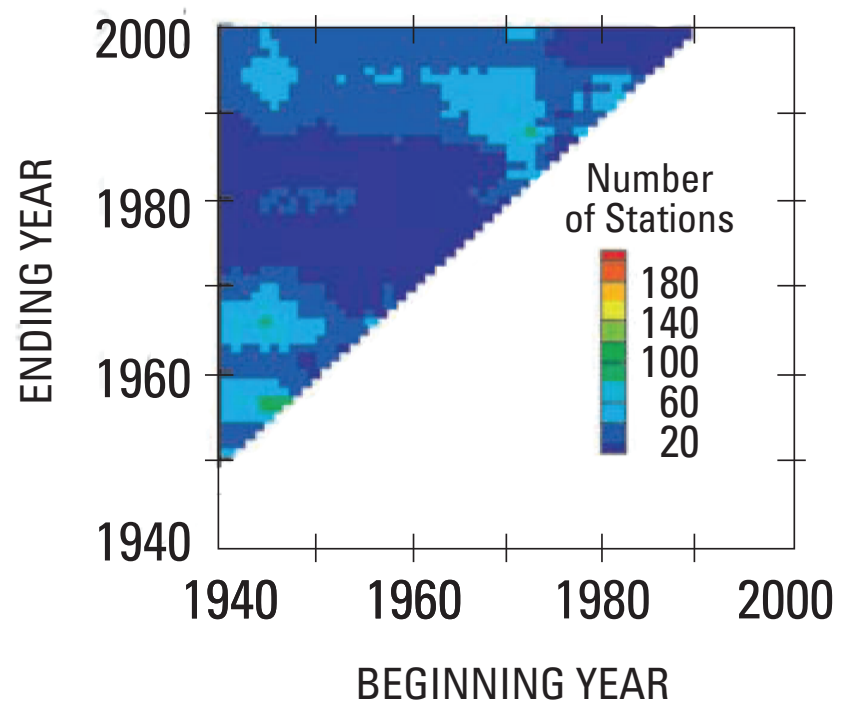

Figure 2. Number of streamgaging stations with statistically significant $(p \leq 0.05)$ increasing and decreasing trends in annual minimum daily streamflow for various periods at least 10 years in length during 1941 through 1999. [Source: McCabe and Wolock, 2002.] 
assessing flood trends is the USGS peak flow file, maintained within the USGS National Water Information System (NWIS) (http://nwis.waterdata.usgs.gov/usa/nwis/peak). Peak flow data represent the maximum instantaneous discharge of water passing a streamgage during each year; although it should be noted that in any given year, even these values may not necessarily represent a true (out-of-bank) flood as most streams do not experience flooding every year.

An example of a peak flow record is shown in figure 3 for the USGS streamgage on the Red River of the North at Grand Forks, North Dakota, for the period 1882-2009. The history of flooding at this site and others in the region is complex. The graph demonstrates the importance of having long-term flow records and carefully and thoroughly examining those records. For example, an analysis of this record for the period 1930-2009 would conclude that there is a substantial upward trend in flood discharges that appears to continue to the present. An association between this trend and contemporaneous increases in greenhouse gas concentrations or land-use change would seem highly plausible if only this part of the record is considered. However, if the entire period of record is assessed, the conclusion is quite different. Considering the entire period, a more likely conclusion is that floods arise from at least two substantially different statistical populations. One population has very large annual peak discharges that prevailed in the years from 1882 to about 1900 and again after about 1942; the other population has much smaller peaks that occurred from about 1900 to 1942. Thus, in considering the entire period of record, it becomes apparent that very large floods were common well before the onset of large increases in greenhouse gases or extensive land modifications. In this case, the data strongly support persistence in climate states as the key mechanism for increased peak flows, rather than a human forcing of change.

One of the most important contributions that the USGS can make to understand better climatic variability and change is to explore the numerous streamflow records that have been collected over the past century, and in some instances longer, and examine flood flows, average flows, seasonal flows, and low flows. Critically, this exploration needs to include

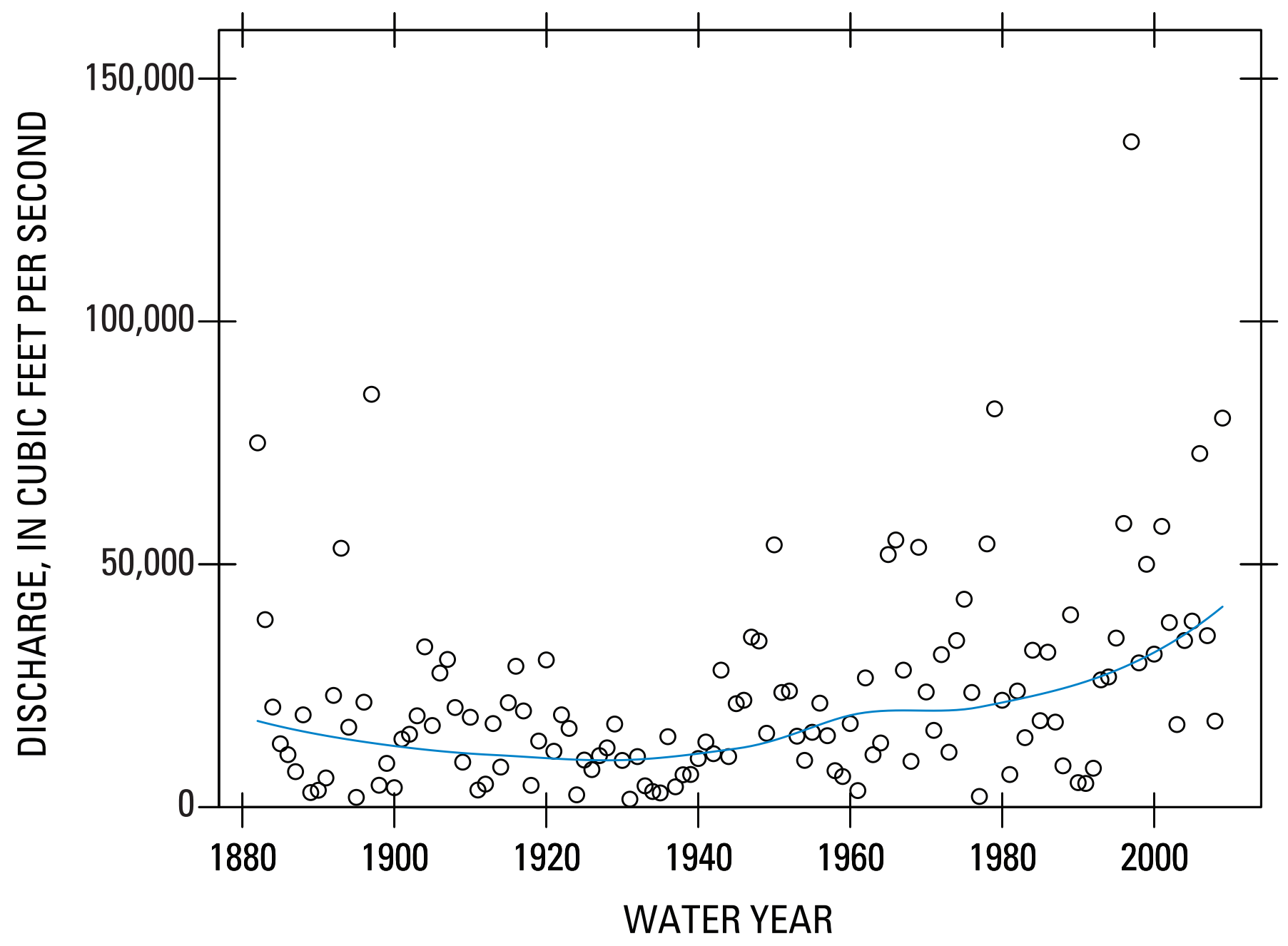

Figure 3. Annual peak discharges, at the USGS streamgage, Red River of the North, Grand Forks, North Dakota, 1882 through 2009. Figure also includes (in blue) a locally weighted smoothed estimate of the changes in the mean flood magnitude over the period of record. 
investigations of both the patterns of change and their relation to a wide range of potential driving variables, including such atmospheric, oceanic, and terrestrial features such as El Niño and the Pacific Decadal Oscillation, as well as greenhouse gas concentrations, and land-use changes in the basin. Waterresources managers and those responsible for flood-plain management and land-use decisions, are looking for answers to how streamflow is changing and where it may be headed in the future. Analysis of datasets, such as the example of annual peak flows from the Red River of the North, is of paramount importance in support of understanding the implications of climatic variability and change for water resources and waterrelated hazards.

Recently, the USGS implemented procedures for assessing the quality of its peak flow records, and for identifying and correcting errors in the records. An appropriate flood database now exists that can be used to help discern if a pattern of change in observed annual peak discharges has occurred. In particular, the questions of greatest interest include: Is there a pattern of change in annual flood peak discharges or flood volumes? Is there a change in the timing of annual peak discharges? Is there a change in the number of largest floods (as defined by exceedances of a particularly high threshold)? Are there an unexpected number of new record peaks (either more or less than would be expected by chance)? Can the role that dams play in changing high-flow characteristics be quantified? Can any observed changes in peak flows be related unambiguously to changes in climatic factors and (or) land-use factors?

\section{Geographical Design}

Obtaining answers to the questions highlighted in the previous section requires a mix of national and regional investigations. Hydroclimatic patterns and events across the United States are a response to highly varying, but geographically persistent, air-mass boundary conditions. Of particular regional interest is the mountainous West, the Northern Plains (Dakotas), and the Northeast, where snowpacks and seasonal river ice create enhanced hydroclimatic sensitivities that can presage critical water-resources variations and change. The gradient from the Continental Divide to just east of the 100th meridian is a highly engineered water-resources environment, with substantially different characteristics from north to south. A suite of comparative east-west transects across the High Plains would provide valuable insight into water balance and low-flow variations. Similarly, gradients from the Appalachians to the Atlantic Coastal Plain, the upper Midwest to the Northern Plains, north-south across the semiarid to arid Intermountain West, and the hurricane-prone areas from Texas to New England each have unique climate-driven waterresources issues that vary considerably from year to year, and where documentation of longer term variations and changes is critical to ensuring the reliability of the Nation's water supply.
In addition to geographically focused studies, there also is a need for issue-oriented investigations that can capitalize on unique characteristics of particular river basins. Issues associated with basins having a large amount of storage in relation to flow, as in the Colorado River Basin; a high percentage of urbanization, such as in the Delaware River Basin; or a high percentage of agriculture or irrigated agriculture, such as in the Missouri River Basin, all pose situations that can be difficult to analyze yet be of enormous consequence to the Nation's economy and resource security. In this regard, studies that focus on reference sites, such as the incipient USGS Climate Effects Network and the USGS Hydrologic Benchmark Network, are vital to identifying and differentiating climatically driven variations and trends from human-induced landscape effects.

In summary, the USGS is uniquely poised to make a major contribution to the understanding of the role that climatic variability and change can have on our Nation's water resources and aquatic ecosystems. The key attributes that will enable the USGS to make that contribution are: (1) the ability to ensure the continued monitoring of a wide range of hydrologic systems (particularly those that already have long records and limited influences of man on the landscape); and (2) the capacity to substantially increase efforts to analyze existing records to understand changes that are taking place and to differentiate the relations of water resources to climate variation, climate change, and direct human activities on the landscape. "The only way to figure out what is happening to the planet is to measure it, and this means tracking changes decade after decade and poring over the records" (Keeling, 2008). This statement should be the guiding principle by which the USGS Climate Effects Network is implemented.

\section{References Cited}

Carlisle, D.M., Falcone, James, Wolock, D.M., Meador, M.R., and Norris R.H., 2009, Predicting the natural flow regime: models for assessing hydrological alteration in streams: River Research and Applications, v. 26, no. 2, p. 118-136. (Also available at http://dx.doi.org/10.1002/rra.1247.)

Dettinger, M. D., and Cayan, D. R., 1995, Large-scale atmospheric forcing of recent trends toward early snowmelt runoff in California: Journal of Climate, v. 8, p. 606-623.

Douglas, E. M., Vogel, R. M., and Kroll, C. N., 2000, Trends in floods and low flows in the United States: impact of spatial correlation: Journal of Hydrology, v. 240, p. 90-105.

Hirsch, R.M., and Norris, J.M., 2001, National streamflow information program: implementation plan and progress report: USGS Fact Sheet FS-048-01, 6 p. (Also available at http://pubs.er.usgs.gov/usgspubs/fs/fs04801.) 
Hodgkins, G.A., and Dudley, R.W., 2006, Changes in the timing of winter-spring streamflows in eastern North America, 1913-2002: Geophysical Research Letters, v. 33, L06402. (Also available at http://dx.doi. org/10.1029/2005GL025593.)

Intergovernmental Panel on Climate Change (IPCC), 1995, Climate Change 1995: The Science of Climate Change, Contribution of Working Group I to the Second Assessment Report of the Intergovernmental Panel on Climate Change: Cambridge University Press, Cambridge, UK.

Intergovernmental Panel on Climate Change (IPCC), 2001, Climate Change 2001: The Scientific Basis. Contribution of Working Group I to the Third Assessment Report of the Intergovernmental Panel on Climate Change: Cambridge University Press, Cambridge, UK.

Intergovernmental Panel on Climate Change (IPCC), 2007, Climate Change 2007: The Physical Science Basis, Contribution of Working Group I to the Fourth Assessment Report of the Intergovernmental Panel on Climate Change: Cambridge University Press, Cambridge, UK.

Keeling, R., 2008, Recording the Earth's vital signs: Science, v. 319 , p. 1771-1772.

Kundzewicz, Z.W., Graczyk, D.J., Maurer, T., Przymusinska, I., Radziejewski, M., Svensson, C., and Szwed, M., 2005, Trend detection in river flow series: 1. Annual maximum flow: Hydrological Sciences Journal, v. 50, p. 797-810.

Langbein, W.B., and others, 1949, Annual runoff in the United States: U.S. Geological Survey Circular 52, 14 p. (Also available at http://pubs.er.usgs.gov/usgspubs/cir/cir52.)

Lins, H.F., and Cohn, T.A., 2003, Floods in the greenhouse: spinning the right tale in Thorndycraft, V.R., Benito, G., Barriendos, M., and Llasat, M.C., eds., Palaeofloods, Historical Data and Climatic Variability: Applications in Flood Risk Assessment, Centro de Ciencias Medioambientales, Madrid, p. 263-268.

Lins, H.F., and Slack, J.R., 1999, Streamflow trends in the United States: Geophysical Research Letters, v. 26, p. 227-230.

Lins, H.F., and Slack, J.R., 2005, Seasonal and regional characteristics of U.S. streamflow trends in the United States from 1940-1999: Physical Geography, v. 26, p. 489-501.

Lins, H.F., and Stakhiv, E.Z., 1998, Managing the nation's water in a changing climate: Journal of the American Water Resources Association, v. 34, p. 1255-1264.

McCabe, G.J., and Clark, M.P., 2005, Trends and variability in snowmelt runoff in the western United States: Journal of Hydrometeorology, v. 6, p. 476-482.
McCabe, G.J., and Wolock D.M., 2002, A step increase in streamflow in the conterminous United States: Geophysical Research Letters, v. 29, p. 2185-2188.

McCabe, G.J., Palecki, M.A., and Betancourt, J.L., 2004, Pacific and Atlantic Ocean influences on multidecadal drought frequency in the United States: Proceedings, National Academy of Sciences, v. 101, p. 4136-4141.

Milly, P.C.D., Wetherald, R.T., Dunne, K.A., and Delworth, T.L., 2002, Increasing risk of great floods in a changing climate: Nature, v. 415, p. 514-517.

Moss, M.E., and Lins, H.F., 1989, Water resources in the twenty-first century - a study of the implications of climate uncertainty: U.S. Geological Survey Circular 1030, 25 p. (Also available at http://pubs.er.usgs.gov/usgspubs/cir/ cir1030.)

Murdoch, P.S., McHale, M.R., Mast, M.A., and Clow, D.W., 2005, The U.S. Geological Survey hydrologic benchmark network: U.S. Geological Survey Fact Sheet 2005-3135, 6 p. (Also available at http://ny.water.usgs.gov/pubs/fs/ $f_{s} 20053135 \%$.)

National Research Council, 1999, Hydrologic Hazards Science at the U.S. Geological Survey: National Academy Press, Washington, D.C., 79 p.

O’Connor, J.E., and Costa, J.E., 2003, Large floods in the United States: where they happen and why: U.S. Geological Survey Circular 1245, 13 p. (Also available at http://pubs. er.usgs.gov/usgspubs/cir/cir1245.)

Pielke, R.A., and Downton, M.W., 2000, Precipitation and damaging floods: trends in the United States, 1932-97: Journal of Climate, v. 13, p. 3625-3637.

Slack, J.R., and Landwehr, J.M., 1992, Hydro-climatic data network: a U.S. Geological Survey streamflow data set for the United States for the study of climate variations, 1874-1988: U.S. Geological Survey Open-File Report 92-129, 193 p. (Also available at http://pubs.usgs.gov/ of/1992/ofr92-129/.)

Stewart, I.T., Cayan, D.R., and Dettinger, M.D., 2005, Changes toward earlier streamflow timing across western North America: Journal of Climate, v. 18, p. 1136-1155.

Svensson, C., Kundzewicz, Z.W., and Maurer, T., 2005, Trend detection in river flow series: 2 . Flood and low flow index series: Hydrological Sciences Journal, v. 50, p. 811-824.

Waggoner, P.E., ed., 1990, Climate Change and U.S. Water Resources: Report of the American Association for the Advancement of Science Panel on Climatic Variability, Climate Change and the Planning and Management of U.S. Water Resources: John Wiley and Sons, New York, 496 p. 
WMO (World Meteorological Organization), 2004, Commission for Hydrology, 12th Session: Abridged Final Report with Resolutions and Recommendations: WMO-No. 979, Geneva, 55 p.

\section{Appendix 1. List of Abbreviations}

$\begin{array}{ll}\text { AMO } & \text { Atlantic Multidecadal Oscillation } \\ \text { CO }_{2} & \text { carbon dioxide } \\ \text { ENSO } & \text { El Niño-Southern Oscillation } \\ \text { GCM } & \text { general circulation model } \\ \text { HBN } & \text { USGS Hydrologic Benchmark Network } \\ \text { HCDN } & \text { USGS Hydro-Climatic Data Network } \\ \text { IPCC } & \text { Intergovernmental Panel on Climate Change } \\ \text { NSIP } & \text { USGS National Streamflow Information } \\ \text { NWIS } & \text { Program } \\ \text { PDO } & \text { Pacific Decadal Oscillation } \\ \text { USGS } & \text { U.S. Geological Survey } \\ \text { WMO } & \text { World Meteorological Organization }\end{array}$


Manuscript approved for publication March 16, 2010.

Prepared by the Reston Publishing Service Center.

Edited by Marilyn A. Billone.

Design and layout by Patricia H. Packard.

For more information, please contact

Dr. Harry F. Lins, U.S. Geological Survey, 415 National Center,

Reston, VA 20192 hlins@usgs.gov. 